\title{
An Analysis of the Relationship Between Board Characteristics and Performance of Listed Commercial Banks in China
}

\author{
Commercial Banks Development Under "Belt and Road "Initiative
}

\author{
Fan $\mathrm{Gu}^{*}$ \\ International Business School \\ Yunnan University of Finance and Economics \\ Kunming, China \\ 33488678@qq.com
}

\author{
Qigeng Chen \\ International Business School \\ Yunnan University of Finance and Economics \\ Kunming, China
}

\begin{abstract}
Along with the implementation of "Belt and road" initiative, commercial banks of China has a great opportunity to develop their oversea business. It required a more reasonable internal governance of banks. Board of directors has played an important role in improving business performance of banks. This article will discuss the relationship between the characteristics of board and business performance of listed commercial banks in China, and provide valuable suggestions for the perfection of governance and promotion of performance of the commercial banks in China. And furthermore, benefit the oversea operation of these banks.
\end{abstract}

Keywords: commercial banks, board of directors, performance

\section{INTRODUCTION}

Since the implementation of the "Belt and Road" initiative, trade exchanges with countries and regions along the route have been growing, and a large amount of capital needs have been generated in infrastructure construction, international capacity cooperation, and foreign trade. The scale of financing has been expanding. This situation can provide an opportunity for international development of commercial banks. By the end of 2018, branches have been set in more than 80 countries. In the term of scale, the oversea assets of domestic commercial banks have reached more than 5 trillion yuan, and the profits from oversea operation have increased. Therefore, commercial banks have played an important role in the process of "Belt and Road" initiative.

However, with the rapid development of globe economy and finance, the commercial banks in China have to face increasingly fierce competitive environment. The internal governance has become an important factor for banks to develop rapidly. Among all of the factors influenced the efficiency of internal governance, more and more scholars have come to the conclusion that perfecting the reasonable board governance mechanism plays a vital role in improving the business performance of banks. The function of board of director has not received enough attention in commercial banks before. Therefore, studying the relationship between board governance and business performance of commercial banks in China can not only understand the current situation of board governance of commercial banks in China, but also pertinently make suggestions in order to improve the performance of banks, which has a good guiding significance to perfect the governance mechanism of commercial banks in China, and will further benefit their oversea development.

In the governance structure of listed companies, the board of directors plays a special role that not only acts as a proxy for shareholders to wield power, but also entrusts senior managers to manage corporate affairs. Therefore, the level of corporate performance is closely related to the governance of board of directors. The board of directors has many functions, such as researching and discussing the strategic development issues of the company, supervising the daily performance of the management, safeguarding the interests of shareholders and so on. The exertion of these functions will affect the performance of the enterprise.

Chinese commercial banks have the internal characteristics of high leverage ratio, transactions in opaque assets and strict control, which make it difficult for the external governance mechanism of Chinese commercial banks to play an effective role, so the internal governance mechanism plays the leading role in the corporate governance of banks. According to the survey and research results, if commercial banks want to improve the effectiveness of internal governance, the best way is to strengthen the functions of the board of directors, in order to improve the supervision and decision-making role of the board of directors (Admas \& Mehran, 2003).

The paper aims to analyze the relationship between the characteristics of board and business performance of listed commercial banks in China, and provide valuable suggestions for the perfection of governance and promotion of performance of the commercial banks in China. And furthermore, benefit the oversea operation of these banks. 


\section{LITERATURE REVIEW}

\section{A. Principal-agent Theory}

Berle and Means (1932) laid a certain foundation for the development of principal-agent theory through their studies on the degree of shareholding separation of 200 listed enterprises in the United States. On account of the separation of enterprise ownership and business management right, two different interest groups are formed in the enterprise, namely resource owners and managers. The contradiction between interests thus leads to agency problem, which then leads to agency cost. The increase of agency cost will lead to the decrease of shareholder's wealth and reduce enterprise value. American scholars Fama and Jensen (1983) believe that the agency cost of enterprises can be reduced through external governance mechanism (capital market) and internal governance mechanism (board of directors).

In principal-agent relationship, "adverse selection" and "moral hazard" are the two most easily caused problems.

Therefore, in order to solve the above problems, Jensen and Fama combine the principal-agent theory with modern corporate governance, pointing out that the board of directors not only regulates the contradictions between all parties, but also guarantees the rights and interests of investors.

\section{B. Resource Dependence Theory}

Different from the emphases of principal-agent theory on the company's internal power relationship, the resource dependence theory proposed by Pfeffer and Salacik (1978) emphasizes the importance of external environmental elements to the birth and development of an organization. The theory holds that the fundamental purpose of establishing a board of directors in modern enterprises is to provide resources for the development of enterprises. In the theory of resource dependence, it emphasized that with the change of internal and external environment, the role of the board of Directors established by enterprises will also change. Therefore, the structure of the board of directors will be affected by uncertainties in the environment, and the internal strategy and operating performance of enterprises will also be greatly affected by the board of directors.

\section{Stakeholder Theory}

Freeman (1984) pointed out that as long as the individuals or groups that can influence the achievement of the company's goals are the stakeholders of the company. The proposal and development of stakeholder theory has played a positive and significant role in corporate governance reform worldwide. They emphasize that the principal-agent problem caused by the separation of ownership and management rights is the root of the internal governance deficiencies. Their view is based on the fact that shareholders are not the only owners of enterprises. As a contractual organization, creditors, employees, consumers and suppliers all bear the residual risks of enterprises, and they should be the owners of enterprises.

\section{Research status of the relationship between board size and corporate performance}

The resolution of the board of directors is mainly made through full communication and coordination after discussing and voting in the meeting. The difficulty of communication and coordination increases with the board size; therefore, the overlarge board size may become an obstacle to the full play of the communication function of the board of directors, and further affecting its decision-making efficiency. However, if the board size is too small, the limited staff cannot provide different opinions, which is also not conducive to the improvement of the quality of board decisions, and then affect corporate performance. There are several views on the relationship between board size and corporate performance:

- Negative correlation: Lipton, Lorsch (1992) and Jensen (1993) conducted studies based on agency theory and concluded that small board size structure is more effective for bank board governance. Sun and Zhang (2000) made regression on panel data of 519 listed companies in China.

- Positive correlation: Adams and Meheran (2003) selected the sample data of some American commercial banks to analyze and the result showed that the larger the board size, the better the business performance of commercial banks. Belkhir (2009) selected the data from 1995 to 2002 of 174 commercial banks for quantitative analysis and the results showed that the reduction of board members would lead to the decline of bank performance.

- Board size and corporate performance has an inverted U-shaped correlation: In this theory, there may be a most economic turning point, where the communication problems caused by too many people and the lack of professional perspectives caused by too few people can be well balanced, and maximize the decision-making efficiency of the board of directors. Yermack (1996) conducted research by using the value of Tobin Q as an indicator to measure the corporate performance. The results show that the relationship between board size and corporate performance is not linear, but a significant inverted U-shaped curve correlation. The empirical study of $\mathrm{Yu}$ (2004) also draws the same conclusion.

\section{E. Research status of the relationship between the ratio of independent directors and corporate performance}

- The ratio of independent directors and corporate performance has a positive correlation: Kor (2006) believes that the effectiveness of the board of directors depends largely on its independence. Rahman, Ibrahim and Ahmad (2015) selected 300 Malaysian listed companies as research samples, using ROE and EPS to measure corporate financial performance, and stock price to measure shareholder confidence. The study believes that the existence of independent directors will improve corporate performance and shareholder confidence. 
- The ratio of independent directors and corporate performance has a negative correlation: Agrawl and Knoeber (1996) argue that the function of independent directors is not as good as expected. Li Changqing and Lai Jianqing (2004) used EVA index, the results show that the independent directors have a negative impact on corporate performance. Lan Yujie and Wang Chunfeng (2010) take listed companies in Anhui Province as the research object and the results turn out that with the increase of the ratio of independent directors in the board of directors, corporate performance shows a downward trend.

\section{F. Summary of this chapter}

Through the principal-agent theory, resource dependence theory and stakeholder theory, and the research status of the relationship between the characteristics of each board of directors and corporate performance, it has fully reflected that the characteristics of the board of directors have a very significant impact on corporate performance. However, there is no consensus among scholars on whether each characteristic is positively or negatively correlated with performance. In addition, the author believes that the impact of board characteristics on corporate performance varies from industry to industry. Therefore, this thesis will use practical questionnaire survey and quantitative analysis to study the relationship between characteristics and performance of board of listed commercial banks in China.

\section{RESEARCH METHOD}

In order to do this research, this thesis uses questionnaire survey and quantitative analysis to study and analyze the impact of board characteristics on business performance of listed commercial banks in China from the perspectives of public awareness and actual situation.

\section{A. Research Hypothesis}

- Board size and bank performance has a negative correlation.

- $\quad$ Ratio of independent directors and bank performance has a positive correlation.

- The number of board meetings annually and bank performance has a positive correlation.

- The proportion of female directors and bank performance has a positive correlation.

- $\quad$ Remuneration of board members and bank performance has a positive correlation.

\section{B. Data Collection}

\section{1) Data collection of questionnaire survey}

From February 15th to March 1st, 2019, the author conducted a questionnaire survey on banker and other employees through the SO JUMP website, in order to obtain the public's understanding of the characteristics and performance of board of listed commercial banks in China, as well as their understanding of the relationship between them.

\section{2) Data collection of questionnaire survey Selection}

This paper takes 16 commercial banks listed in China as the research object, as shown in Table I.

TABLE I RESEARCH OBJECT: 16 LISTED COMMERCIAL BANKS IN CHINA Bank of China Ping An Bank Bank of Communications Shanghai Pudong Development Bank \begin{tabular}{|l|l|l|l}
\hline Industrial Bank & Bank of Ningbo & China Merchants Bank & China M insheng Banking Corp
\end{tabular} Hua Xa Bank China Citic Bank China Construction Bank Industrial and Commercial Bank of China \begin{tabular}{l|l|l|l} 
Bank of Beijing & Bank of Nanjing & China E verbright Bank the Agricultural Bank of $\mathrm{C}$ hina
\end{tabular}

These banks almost cover the main forms of domestic commercial banks. Moreover, these banks are relatively large in scale and have a long development time with rich management experience. All the financial data and board characteristics related data needed in this thesis are from GTA database and the annual reports of listed companies of commercial banks from 2008 to 2017.

\section{DATA DESCRIPTION}

\section{A. Questionnaire survey data description}

A total of 152 questionnaires and 152 valid questionnaires were collected in this survey. Because the total sample size is small, the conclusion may be biased. Thirteen questions were designed in this questionnaire to obtain the public's views on the impact of board characteristics on performance.

\section{B. Quantitative analysis data description}

This paper collects the required data from the annual reports of 16 listed commercial banks in China from 2008 to 2017. Because of the excessive data, only the data for 2017 are listed here, as shown in the tables.

\begin{tabular}{|c|c|c|c|c|c|}
\hline Bank name & $\begin{array}{l}\text { Fetum on wotal } \\
\text { assets (\%) }\end{array}$ & $\begin{array}{l}\text { Nonpertoming } \\
\text { loan ste (\%) }\end{array}$ & $\begin{array}{c}\text { Deposit-losn rasio } \\
(\%)\end{array}$ & $\begin{array}{l}\text { Total as sets at the end of } \\
\text { the year }\end{array}$ & $\begin{array}{l}\text { As set-iability } \\
\text { stio (\%) }\end{array}$ \\
\hline Ping An Bark & 0.7478 & 1.7000 & 83.5900 & $\approx 3,248,474,000,000.00$ & 93.1644 \\
\hline Eark of Ningoo & 0.9780 & 0.8200 & 580000 & $¥ 1,032.042,442,000.00$ & 94.4570 \\
\hline Shanghai Pubong Deveo pment Bark & 0.9171 & 2,1400 & 105.1509 & (6. $137,240,000,0000.00$ & 929775 \\
\hline $\mathrm{H}$ ia X Bank & 0.8194 & 1.7600 & 88.0400 & $\$ 2,508,927,000,0000.00$ & 932442 \\
\hline Mrsheng Barking Cop & 0.8032 & 1.7100 & 94.5385 & *5,902,008,000,000.00 & 93,3954 \\
\hline Oina Necharts Bank & 1.1542 & 1.6100 & 87.7151 & $\$ 6.297 .0380000,000.00$ & 923242 \\
\hline Bark of Naning & 0.8853 & 0.8800 & 53.8300 & $¥ 1,141,162,795,000.00$ & 94.0227 \\
\hline Industial Bark & 0.9236 & 1.5900 & 787424 & *6, 416,842,000,000,00 & 99.4118 \\
\hline Bark of Being & 0.8494 & 1.2400 & 84.8981 & $\$ 2,329,005,000,0000.00$ & 924151 \\
\hline the Agricutual Bark of Cins & 0.9508 & 1.8100 & 51.0000 & $\$ 21,053,382,000,000,00$ & 932108 \\
\hline Bark of Communic ations & 0.8106 & 1.5000 & 90.3976 & $\$ 9,038,254,000,000.00$ & 925177 \\
\hline houstrial and Commercial Bank of China & 1.1447 & 1.5500 & 71.1000 & $\$ 26,087,043,000,00000$ & 91.7928 \\
\hline Cins Evebrigtt Bsck & 0.7797 & 1.5900 & 89.4129 & $\$ 4,088,243,000,0000.00$ & 925289 \\
\hline Cina Constuction Bark & 1.1308 & 1.4900 & 70,7300 & $₹ 22,124,383,000,00000$ & 91.8830 \\
\hline Bark of Cins & 0.9835 & 1.4500 & 79.7819 & $\$ 19,467,424,000,000000$ & 91.9009 \\
\hline Gins Otoc Bark & 0.7387 & 1.6900 & 93.8154 & $\approx 5,677,691,000,000.00$ & 927359 \\
\hline
\end{tabular}


TABLE III DATA OF BANKS IN 2017

\begin{tabular}{|c|c|c|c|c|c|}
\hline Bank name & $\begin{array}{l}\text { Total number of } \\
\text { diectors }\end{array}$ & $\begin{array}{l}\text { Number of } \\
\text { independent } \\
\text { directors }\end{array}$ & $\begin{array}{l}\text { Number of Enale } \\
\text { directors }\end{array}$ & $\begin{array}{l}\text { Number of Board } \\
\text { Meatings }\end{array}$ & $\begin{array}{l}\text { The sum of the tof } \\
\text { three } \\
\text { director's salaries }\end{array}$ \\
\hline Ping An Bark & 14 & 5 & 3 & 10 & $\approx 9,448,900,00$ \\
\hline Bank of Ningbo & 17 & 5 & 5 & 9 & $¥ 7,830,000.00$ \\
\hline $\begin{array}{l}\text { Shanghai Pudorg } \\
\text { Development Bark }\end{array}$ & 15 & 7 & 1 & 13 & $¥ 8,221,200.00$ \\
\hline $\begin{array}{l}\text { Shanghai Pudong } \\
\text { Deelopopment Bark }\end{array}$ & 18 & 6 & 1 & 9 & $¥ 2,920,800.00$ \\
\hline Minsherg Banking Copp & 18 & 8 & 0 & 11 & $¥ 12,488,800.00$ \\
\hline China Merchants Bank & 16 & 6 & 4 & 12 & $¥ 9,968,000.00$ \\
\hline Bank of Nanjing & 13 & 5 & 3 & 9 & $¥ 1,758,200.00$ \\
\hline Industrial Bank & 15 & 5 & 0 & 5 & $¥ 2,907,420.00$ \\
\hline Bark of Bejing & 16 & 6 & 6 & 12 & $¥ 2,379,500.00$ \\
\hline $\begin{array}{c}\text { the Agricultural Bank of } \\
\text { China }\end{array}$ & 15 & 5 & 2 & 14 & $¥ 1,983,800,00$ \\
\hline Bark of Conmunications & 18 & 8 & 3 & 8 & $¥ 2,148,300.00$ \\
\hline $\begin{array}{c}\text { Industrial and Commercial } \\
\text { Bank of China }\end{array}$ & 16 & 6 & 4 & 9 & $¥ 1,851,000.00$ \\
\hline China Eletoright Bank & 14 & 6 & 2 & 11 & $¥ 3,182,200.00$ \\
\hline China Constructon Bark & 15 & 5 & 3 & 9 & $¥ 1,871,800,00$ \\
\hline Bank of China & 13 & 4 & 3 & 10 & $¥ 1,945,300.00$ \\
\hline China Citic Bank & 11 & 5 & 4 & 10 & $¥ 2,596,800,00$ \\
\hline
\end{tabular}

\section{Variable selection}

\section{1) Explained variable}

Following the principles of comprehensiveness, consistency and operability, this thesis considers profitability, security and liquidity comprehensively, and chooses three indicators to measure the bank performance, namely, return on total assets, ratio of non-performing loan and deposit-loan ratio.

- Profitability: The greater the return on total assets, the better the profitability of the bank.

- Security: The higher the non-performing loan ratio, the lower the security of the bank and the worse the risk control ability.

- Liquidity: The higher the deposit-loan ratio, the lower the bank's liquidity. However, the lower the bank's liquidity is within a certain range means the better the bank's profit performance will be.

\section{2) Explaining variable}

After selection, five explaining variables are selected, including the board size, ratio of independent directors, the number of annual board meetings, the remuneration of board members and the proportion of female directors.

\section{3) Control variable}

The paper selects two control variables referring to the previous studies, namely total assets and asset-liability ratio.

\section{DATA ANALYSIS}

\section{A. Questionnaire survey}

According to this survey, most of the participants indicate that the characteristics of the board of directors of listed commercial banks in China are closely related to bank performance. In order to explore the relationship between the two more objectively, this thesis will use quantitative analysis to study the relationship between board characteristics and bank performance of listed commercial banks in China.

\section{B. Quantitative analysis} TABLE IV VARIABLE SELECTIONS

\begin{tabular}{|c|c|c|}
\hline \multirow{4}{*}{ dependent variable } & $Y 1$ & Return on total assets \\
\cline { 2 - 3 } & $Y 2$ & Non-performing loan rate \\
\cline { 2 - 3 } & $Y 3$ & Deposit-loan ratio \\
\hline \multirow{5}{*}{ independent variable } & $X 1$ & Total number of directors \\
\cline { 2 - 3 } & $X 2$ & Number of independent directors \\
\cline { 2 - 3 } & $X 3$ & Number of female directors \\
\cline { 2 - 3 } & $X 4$ & Number of Board Meetings \\
\cline { 2 - 3 } & $X 5$ & The sum of the top three directors'salaries \\
\hline \multirow{3}{*}{ control variable } & $X 6$ & Total assets at the end of the year \\
\cline { 2 - 3 } & $X 7$ & Asset-liability ratio \\
\hline
\end{tabular}

Set the regression model of bank board characteristics on return on total assets as:

$Y 1=\alpha 1+\beta 1 * X 1+\beta 2 * X 2+\beta 3 * X 3+\beta 4 * X 4+\beta 5 * X 5+\beta$ $6 * X 6+\beta 7 * X 7$

Set the regression model of bank board characteristics on nonperforming loan ratio as:

$Y 2=a 2+\gamma 1 * X 1+\gamma 2 * X 2+\gamma 3 * X 3+\gamma 4 * X 4+\gamma 5 * X 5+\gamma$ $6 * X 6+\gamma 7 * X 7$

Set the regression model of bank board characteristics depositloan loan ratio as:

$Y 3=a 3+\delta 1 * X 1+\delta 2 * X 2+\delta 3 * X 3+\delta 4 * X 4+\delta 5 * X 5+\delta$ $6 * X 6+\delta 7 * X 7$

Among them, a $1, \alpha 2, \alpha 3$ are constant terms, $\{\beta 1, \beta$ $2, \beta 3, \beta 4, \beta 5, \beta 6, \beta 7\},\{\gamma 1, \gamma 2, \gamma 3, \gamma 4$, $\gamma 5, \gamma 6, \gamma 7\},\{\delta 1, \delta 2, \delta 3, \delta 4, \delta 5, \delta 6, \delta 7\}$ are independent variable coefficients.

1) Testing whether the model conforms to normal distribution

TABLE V HISTOGRAM

histogram

Dependent variable: return on total assets (\%).

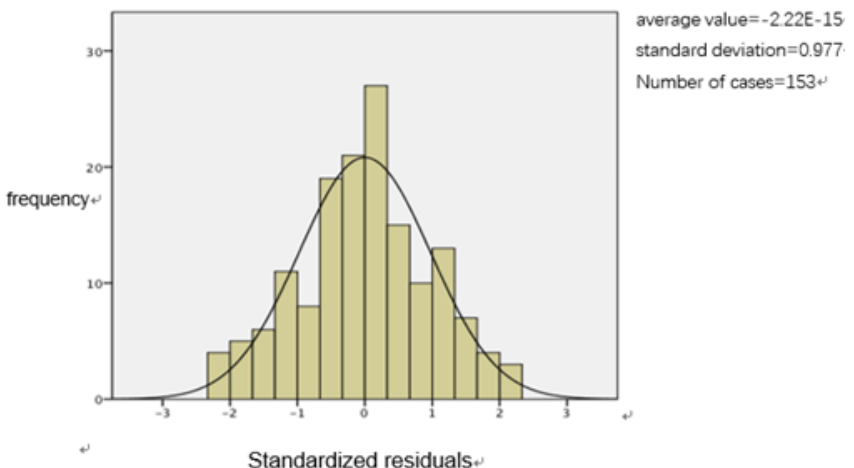


TABLE VI NORMAL P-P CHART OF STANDARD

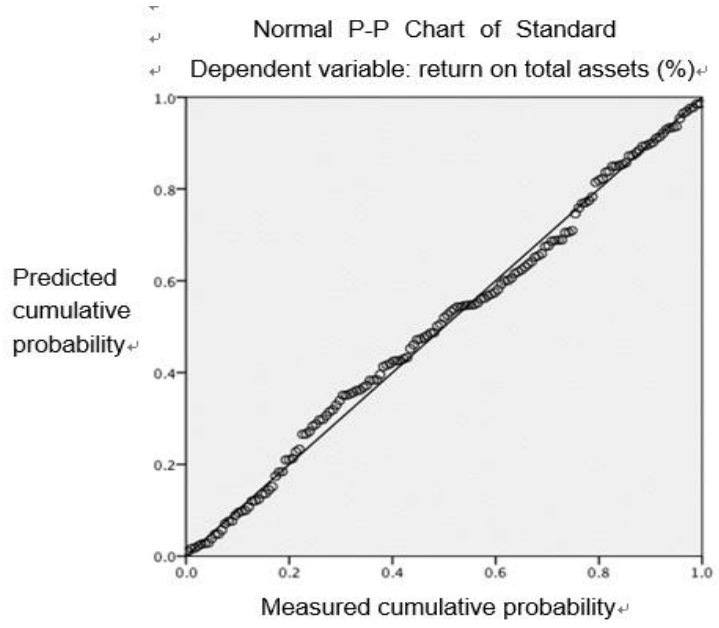

The histogram and normal probability graph of standardized residuals show that the residuals conform to normal distribution.

2) Results of Multivariate regression analysis

Under the $95 \%$ confidence interval, the total number of board directors is positively correlated with the return on total assets, the asset-liability ratio is negatively correlated with the return on total assets, and other variables are not significantly correlated with the return on total assets. The total assets at the end of the year have a negative correlation with the nonperforming loan ratio, while other variables have no significant impact on it. The number of independent directors has a positive correlation with the deposit-loan ratio. The number of board meetings is positively correlated with the deposit-loan ratio, while the asset-liability ratio is negatively correlated with the deposit-loan ratio. Other variables have no significant impact on the deposit-loan ratio.

\section{3) Results of multivariate regression analysis}

- The coefficient of total number of directors and return on total assets is positive, but it does not pass the $95 \%$ significance test, so the total number of directors has nothing to do with the return on total assets, that is, there is no obvious correlation between the size of directors and the profitability of banks. The total number of directors is negatively correlated with the non-performing loan ratio, which indicates that the more the number of directors, the stronger the risk resistance ability of banks.

- There is no significant correlation between the number of independent directors and the return on total assets. The number of independent directors is negatively correlated with the non-performing loan ratio, which indicates that the larger the proportion of independent directors, the stronger the bank's ability to resist risks. The number of independent directors is positively correlated with the deposit-loan ratio, which indicates that the larger the proportion of independent directors, the lower the liquidity of bank funds, but it improves the profitability of banks on the other hand.

- The number of board meetings has no significant correlation with the return on total assets and the nonperforming loan ratio, but has a significant positive correlation with the deposit-loan ratio.

- There is no correlation between the number of female directors and the three dependent variables.

- There is no significant correlation between the sum of salary of the top three directors and the return on total assets and the deposit-loan ratio, while it has a significant negative correlation with the nonperforming loan rate.

\section{CONCLUSION}

\section{A. Conclusion}

The conclusion of the questionnaire survey is that the majority of the public thinks that:

- Oversize and undersize enterprise scales are not conducive to the quality assurance of meeting decisions.

- Independent directors of listed commercial banks in China are conducive to improving corporate performance.

- Frequent board meetings may be a reflection of deterioration of corporate performance.

- More female directors in the board of banks has no effect on the improvement of corporate performance.

- High salary can effectively improve corporate performance.

In order to express the research results more clearly, the regression conclusions between the characteristics of the board of directors and the profitability, risk control ability and asset liquidity of banks are arranged as follows:

TABLE VII REGRESSION ANALYSIS CONCLUSION

\begin{tabular}{|c|c|c|c|}
\hline $\begin{array}{c}\text { Board } \\
\text { characteristics }\end{array}$ & Profitability & Risk control ability & Asset liquidity \\
\hline Board size & None & Positive & None \\
\hline $\begin{array}{c}\text { Ratio of independent } \\
\text { directors }\end{array}$ & None & Positive & Negative \\
\hline $\begin{array}{c}\text { The number of } \\
\text { board meetings }\end{array}$ & None & None & Negative \\
\hline $\begin{array}{c}\text { The proportion of } \\
\text { female directors }\end{array}$ & None & None & None \\
\hline $\begin{array}{c}\text { The remuneration of } \\
\text { board members }\end{array}$ & None & Positive & None \\
\hline
\end{tabular}

\section{B.Suggestion}

1) To control the the board size of commercial Banks 
The board size of commercial banks is generally controlled at a certain level mainly because of the strict supervision of commercial banks. If the board size is too large, when there is disagreement among the board members and communication contradictions exist, of course the "free-ride" phenomenon will appear. It is also suggested that different commercial banks may determine the board size according to the development stage of the bank. Thus, when establishing the number of board members, commercial banks should consider the development stage, asset size and business development of the bank, and make some appropriate adjustments to ensure that the board of directors can effectively supervise the operation of the bank and make efficient decisions.

2) To perfect the independent director system of commercial banks

It can be seen that the participation of independent directors has a positive impact on bank performance. Due to the low proportion of independent directors in Chinese commercial banks, it is necessary to increase the ratio of independent directors appropriately under the given board size especially the independent directors elected by employees. Therefore, the way of appointing independent directors should also be open and diversified. Besides, commercial banks should gradually establish a talent pool of independent directors

\section{3) To formulate reasonable incentive system}

The salary incentive mechanism of directors in Chinese commercial banks is mainly based on annual salary. Reasonable incentive mechanism should be related to the corporate operating performance, and payable by instalment system can be gradually established, that is, when operating performance declines, besides the annual salary of directors in that year will be affected, the salary of directors in the previous year will also be deducted, which can truly achieve the effect of encouraging directors to work hard. In addition, commercial banks should properly promote the incentive method of equity incentives, and gradually establish and perfect a reasonable long-term incentive mechanism.

\section{4) To recruit high-quality female directors}

Commercial banks should give more opportunities to female when choosing directors and encourage more excellent women to participate actively in the important decisionmaking of the board of directors. Commercial banks should give more care and support to women in training managers, performance evaluation, welfare policy and bonus payment system, especially should consider the special factor of female reproduction and breastfeeding, so that they can get better protection in promotion.

To conclusion, better play the role of board of directors, could not only improve the performance of commercial banks in China, but also promote the oversea operations and serve the implementation of "Belt and Road" Initiative. Banks should grab the opportunity and create new achievements.

\section{C.Limitation and future research}

The sample size is not big enough to establish solid conclusion. The performance may be the cause of more board meetings from the practical view. Therefore, to exchange the variable and independent variable may come different result. For the oversea branches of commercial banks, identify their unique characteristics can help to provide more practical and valuable information to improve operation. More research can be done on this direction.

\section{ACKNOWLEDGMENT}

I would like to express my thanks to copartner Chen Qicheng, he has put much efforts on this paper and give me many help and support. In addition, I would like to thank the participants of the questionnaires. Thanks to the funding provided by YUFE Research Project. At last, I want to express my appreciation to the reviewers for the valuable comments and suggestions.

\section{REFERENCES}

[1] Adams, R. B., \& Ferreira, D. (2009). Women in the boardroom and their impact on governance and performance $z$. Social Science Electronic Publishing, 94(2), 291-309.

[2] Adams, R. B., \& Mehran, H. (2003). Is corporate governance different for bank holding companies?. Federal Reserve Bank of New York Economic Policy Review, 9(Apr), 123-142.

[3] Agrawal, A., \& Knoeber, C. R. (1996). Firm performance and mechanisms to control agency problems between managers and shareholders. Journal of Financial \& Quantitative Analysis, 31(3), 377 397.

[4] Belkhir, M. (2009). Board structure, ownership structure and firm performance: evidence from banking. Applied Financial Economics, 19(19), 1581-1593.

[5] Bhagat, S., \& Black, B. (1999). The uncertain relationship between board composition and firm performance. Business Lawyer, 54(3), 921 963.

[6] Bhatt, R. R., \& Bhattacharya, S. (2015). Board structure and firm performance in indian it firms. Journal of Advances in Management Research, 12(3), 232-248.

[7] Campbell, K., \& Minguezvera, A. (2008). Gender diversity in the boardroom and firm financial performance. Journal of Business Ethics, 83(3), 435-451.

[8] Erhardt, N. L., Werbel, J. D., \& Shrader, C. B. (2010). Board of director diversity and firm financial performance. Corporate Governance An International Review, 11(2), 102-111.

[9] Gul, F. A., Srinidhi, B., \& Ng, A. C. (2011). Does board gender diversity improve the informativeness of stock prices?. Journal of Accounting \& Economics, 51(3), 314-338

[10] Hillman, A. J., Cannella, A. A., \& Paetzold, R. L. (2010). The resource dependence role of corporate directors: strategic adaptation of board composition in response to environmental change. Journal of Management Studies, 37(2), 235-256.

[11] Malik, M. S., \& Makhdoom, D. D. (2016). Does corporate governance beget firm performance in fortune global 500 companies?. Corporate Governance, 16(4), 747-764.

[12] Sun, L., Zhou, L. (2016). Female directors, over-investment and performance fluctuation: based on the perspective of prudence. Management Review, 28(07), 165-178. 